\title{
Mantle Dynamics beneath Mongolia: Implications from Cenozoic and Mesozoic Alkalic Basalts
}

Barry, T.L.' (tlb2@leicester.ac.uk), Kempton, P.D.² (p.kempton@nigl.nerc.ac.uk), Saunders, A.D.' (ads@leicester.ac.uk) and Windley,B.' (bfw@leicester.ac.uk)

1. Department of Geology, Leicester University, University Road, Leicester, UK LE1 7RH

2. NERC Isotope Geosciences Laboratory, British Geology Survey, Keyworth, UK NG12 5GG

\section{Introduction}

Cenozoic and Cretaceous alkali basalts occur diffusely across an area of $180,000 \mathrm{~km}^{2}$ in Central Mongolia. The Cenozoic volcanism relates to two distinct tectonic settings: one due to localized extension associated with strike-slip faults in the Gobi (33-30Ma), the other related to small-scale rifts adjacent to an uplifted dome, the Hangai (6 - 0.004Ma). Mesozoic magmatism (117-95 Ma) is restricted to the Gobi region, and pertains to a phase of rifting most active in the late JurassicEarly Cretaceous.

\section{Asthenosphere vs. Lithosphere vs. Crustal Contamination?}

Mg numbers of up to 65 are observed among Cenozoic basalts and up to 67 for some Mesozoic lavas, indicating that the sample suite as a whole is quite primitive and unfractionated. Furthermore, on a plot of ${ }^{87} \mathrm{Sr} /{ }^{86} \mathrm{Sr}$ vs. $\mathrm{Sr}(\mathrm{ppm})$, the data show that there has not been significant assimilation of continental crust (Fig. 1). The only samples that show significant amounts of crustal contamination are the earliest lavas of the Mesozoic rifting phase; this is also indicated from extended trace element plots. Both Cenozoic and Cretaceous basalts show $\mathrm{La} / \mathrm{Ba}$ versus $\mathrm{La} / \mathrm{Nb}$ ratios similar to those of ocean island basalts. High $\mathrm{La} / \mathrm{Yb}(25.0-30.5)$ ratios in lavas from both Cenozoic tectonic settings (i.e. Gobi and Hangai) indicate residual garnet in the source; whereas Mesozoic samples have lower $\mathrm{La} / \mathrm{Yb}$ ratios (10.3-18.9), suggesting little or no residual garnet. Thus, the data are consistent with an increase in the average depth of melting since the Mesozoic. The deep signature for the Cenozoic basalts is present even though the samples span $>30$ m.y. with a hiatus of $\sim 24$ m.y. between those erupted at the different tectonic settings. Hf isotope analyses in progress may help to constrain this variation with time.

A plot ${ }^{143} \mathrm{Nd} /{ }^{144} \mathrm{Nd}$ versus ${ }^{87} \mathrm{Sr} /{ }^{86} \mathrm{Sr}$ (Fig.2) for all basalts, compared with

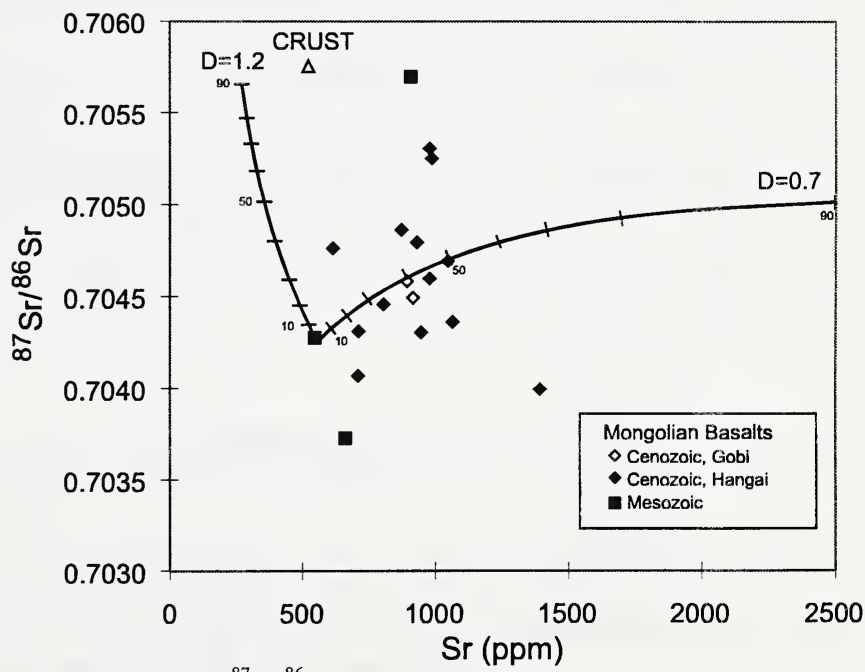

Fig. 1. Plot of ${ }^{87} \mathrm{Sr} /{ }^{86} \mathrm{Sr}$ vs. $\mathrm{Sr}$ (ppm). Hypothetical crustal end member from Stosch et al. (1995). Mongolian basalts do not lie on any AFC modelling curves (DePaolo, 1981) show that crustal contamination is not a significant process in their petrogenesis. Even if multiple curves are hypothesized, the amount of contamination required is in excess of that acceptable while still preserving the high Mg\#'s of the lavas. 


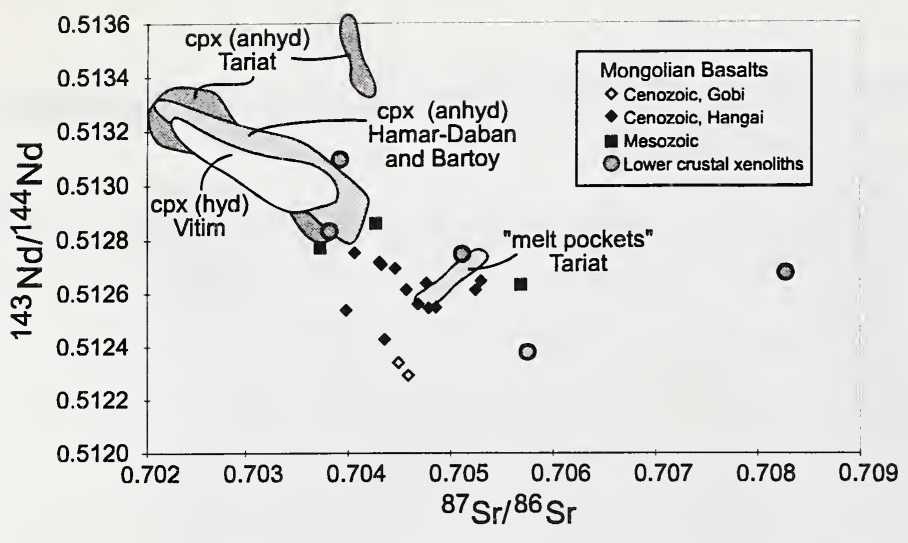

Figure 2. Plot of ${ }^{87} \mathrm{Sr} /{ }^{86} \mathrm{Sr}$ vs ${ }^{143} \mathrm{Nd} /{ }^{144} \mathrm{Nd}$ for Mongolian basalts compared with peridotite data from surrounding areas in Mongolia and Baikal; data sources: cpx (anhydr), Tariat - Ionov et al. (1994); melt pockets - Stosch et al. (1986); cpx (hyd), Bartoy - Ionov et al. (1992); cpx (anhydr), Hamar Daban and Bartoy - Ionov et al. (1992; 1995). Data for crustal xenoliths from Stosch et al. (1995) and this study. See text for discussion. published crustal xenolith data, indicates that the basalts are from a less depleted source than most of the xenoliths. One explanation for this is that the basalts were produced by mixing between lithosphere-derived melts (i.e. low $\varepsilon N d$-high $\varepsilon S r$ ) and the continental crust represented by the xenoliths. However, given that major element and $\mathrm{Sr}$ isotope systematics suggest little, if any, crustal contamination of the Cenozoic lavas has occurred, we believe that these basalts are derived by interaction between enriched lithosphere and asthenosphere-derived melts as they ascend to the surface.

\section{Mantle Dynamics beneath Mongolia}

The prolonged activity and widespread dispersion of volcanism in the Cenozoic has been attributed to numerous models: 'extension' tectonics as a long-distance effect of India-Asia collision (Molnar and Tapponnier, 1975), a long-lived mantle plume (Yarmolyuk et al., 1990), a newly arrived plume centered beneath Hangai (Windley and Allen, 1993), and a shallow sheet-like thermal anomaly (Barry and Kent, in press). The absence of progressively aged volcanism or high heat flow, coupled

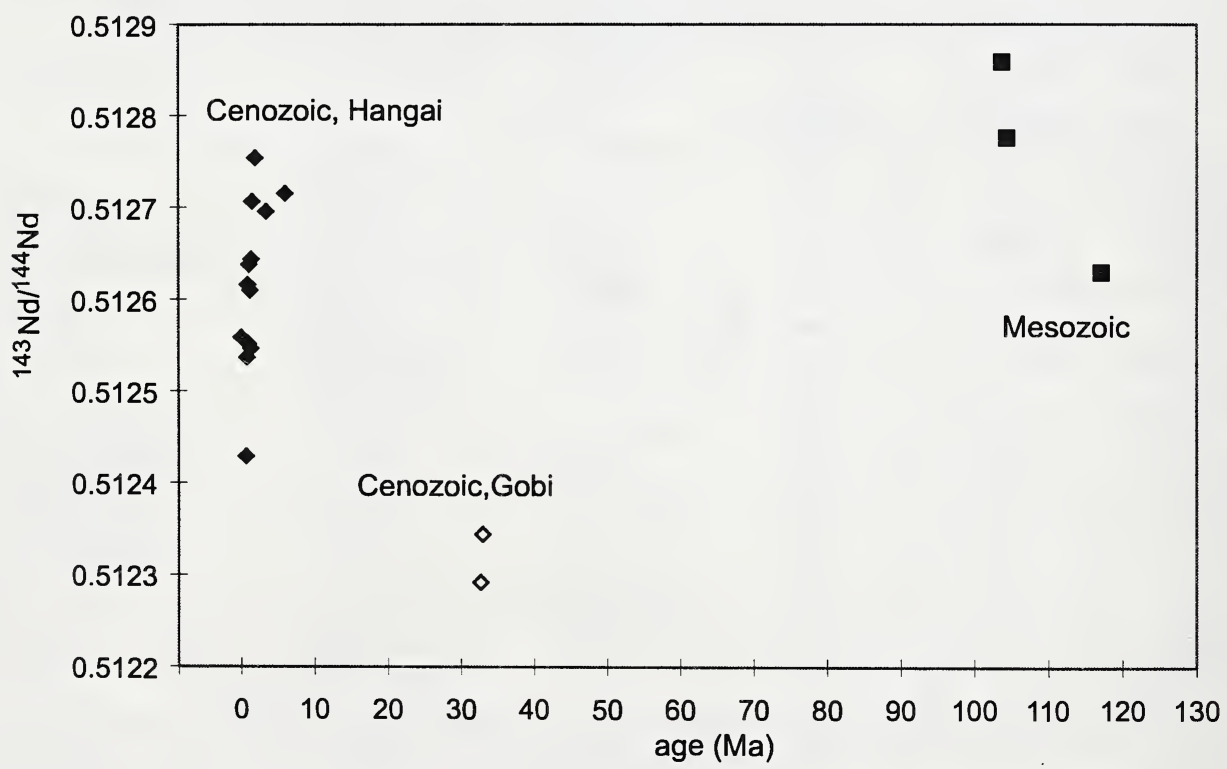

Figure 3. Plot of age vs. ${ }^{143} \mathrm{Nd} /{ }^{144} \mathrm{Nd}$. Sources of age data: Mesozoic and Cenozoic Gobi $-{ }^{40} \mathrm{Ar} /{ }^{39} \mathrm{Ar}$ (T. Barry, unpublished), Cenozoic Hangai $-{ }^{40} \mathrm{Ar} /{ }^{39} \mathrm{Ar}$ (Schlupp, pers. comm. and Ionov, pers comm.) combined with estimated ages based on field relationships (T. Barry, unpublished). 
with ${ }^{3} \mathrm{He} /{ }^{4} \mathrm{He}$ ratios of $6.5-10.5 \pm<30 \%$ (R/Ra higher than MORB, but lower than deep mantle plume signatures), implies the volcanism may be derived from normal OIB-like mantle (T. L. Barry and G. Davies, upblished data). Therefore, the main control on volcanism may be tectonic thinning or fracturing of the lithosphere above an otherwise homogeneous thermal anomaly that has probably been present since the Mesozoic.

A plot of ${ }^{143} \mathrm{Nd} /{ }^{144} \mathrm{Nd}$ versus time (Fig. 3) summarizes the sequence of events that can be inferred from the Mongolian basalt data. First, the low $\mathrm{Nd}$ isotope ratios of some of the earliest Mesozoic basalts $(\sim 0.5126)$ is consistent with the interpretation that these were contaminated by continental crust. Later, however, when extension was at its greatest and less crust was assimilated, OIB-like ratios are seen (i.e. 0.5128-0.5129). After a 70 m.y. hiatus, the Gobi lavas erupted, having very low ${ }^{143} \mathrm{Nd} /{ }^{144} \mathrm{Nd}$ ratios; this deviation to low ${ }^{143} \mathrm{Nd} /{ }^{144} \mathrm{Nd}$ is not well understood, but as discussed above, it does not appear to be related to crustal contamination. Instead, the Gobi basalts appear to be derived from enriched lithospheric mantle. The younger Cenozoic Hangai basalts have Nd isotope compositions intermediate between the Gobi and the Mesozoic lavas. This trend to higher $\mathrm{Nd}$ isotope compositions in the youngest lavas may also relate to a thinning of the crust and lithospheric mantle. That is, as magmatism proceeded during the Cenozoic, the enriched portions of lithosphere were progressively removed, leaving behind a more depleted, asthenosphere-like source. A similar model has been proposed for the evolution of Cenozoic lavas from the western U.S.A (Kempton et al., 1991; Perry et al., 1987), suggesting that there may be parallels in some aspects of the tectonic evolution of these two regions.

\section{References}

Barry, T.L. and Kent, R.W., in press, Cenozoic magmatism in Mongolia and the origin of Central and East Asian basalts, AGU Geodynamics Series, Monograph, (M. Flower, ed) "Plate Motions and Lithospheric Dynamics in East Asea".

DePaolo, D., 1981, Trace element and isotopic effects of combined wallrock assimilation and fractional crystallization, Earth Plan. Sci. Lett.: v. 53, p. 189-202.

Ionov, D.A., Hofmann, A.W. and Shimizu, N., 1994, Metasomatism-induced melting in mantle xenoliths from Mongolia: J. Petrol. v. 35, p. 753-785.

Ionov, D.A., Kramm, U. and Stosch, H..-G., 1992, Evolution of the upper mantle beneath the southern Baikal rift zone: a Sr-Nd isotope study of xenoliths from the Bartoy volcanoes: Contrib. Mineral. Petrol, v. 111, p. 235-247.

Ionov, D.A., O'Reilly, S.Y., and Ashchepkov, I.V., 1995, Feldspar-bearing lherzolite xenoliths in alkali basalts from Hamar-Davan, southern Baikal region, Russia: Contrib. Mineral. Petrol., v. 122, p. 174-190.

Kempton, P.D., Fitton, J.G., Hawkesworth, C.J. and Ormerod, D.S., 1991, Isotopic and trace element constraints on the composition and evolution of the lithosphere beneath the southwestern United States: J. Geophys. Res., v. 96, p. 13713-13735.

Molnar, P. and Tapponier, P., 1975, Cenozoic tectonics of Asia: effects of a continental collision: Science, v. 189, p. 419-426.

Perry, F.V., Balridge, W.S., and DePaolo, D.J., 1987, Role of asthenosphere and lithosphere in the genesis of late Cenozoic basaltic rocks from the Rio Grande Rift and adjacent regions of the southwestern United States: J. Geophys. Res., v. 92, p. 9193-9213.

Stosch, H.-G., Ionov, D.A., Puchtel, I.S., Galer, S.J.G. and Sharpouri, A., 1995, Lower crustal xenoliths frm Mongolia and their bearing on the nature of the deep crust beneath central Asia,:Lithos, v. 36, p. 227-242.

Windley, B.F. and Allen, M.B., 1993, Mongolian plateau: evidence for a late Cenozoic mantle plume under Central Asia: Geology, v. 21, p. 295-298.

Yarmolyuk, V.V., Kovalenko, V.I., Bogatikov, O. A., 1990, The south Baikal mantle hot spot and its role in the development of the Baikal rift zone, Akademiya Nauk SSSR Doklady: v. 312, p. 93-96. 